\title{
Effect of drinking water temperature on water intake and performance of dairy calves
}

\author{
A. Huuskonen, ${ }^{* 1}$ L. Tuomisto, $†$ and R. Kauppinen $\neq$ \\ ${ }^{*}$ MTT Agrifood Research Finland, Animal Production Research, FI-92400 Ruukki, Finland \\ †MTT Agrifood Research Finland, Animal Production Research, Fl-71750 Maaninka, Finland \\ $¥$ Savonia University of Applied Science, FI-74101 lisalmi, Finland
}

\section{ABSTRACT}

Very limited information is available on the effects of drinking water temperature on dairy calves. Therefore, the present experiment was designed to study the effects on performance, health, and water consumption of dairy calves offered drinking water either warm (16 to $18^{\circ} \mathrm{C}$ ) or cold $\left(6\right.$ to $\left.8^{\circ} \mathrm{C}\right)$. The calves (60 calves/ treatment) were housed in an insulated barn in pens $(3.0 \times 3.5 \mathrm{~m} ; 5$ calves in each $)$ providing $2.1 \mathrm{~m}^{2} /$ calf. During the experimental period (20 to $195 \mathrm{~d}$ of age), the calves had free access to water from an open water bowl (depth $80 \mathrm{~mm}$, diameter $220 \mathrm{~mm}$, 2-L capacity, $1 \mathrm{bowl} / \mathrm{pen}$ ). During the preweaning period (20 to 75 $\mathrm{d}$ of age), all calves received milk replacer $(7.5 \mathrm{~L} /$ calf daily) and had free access to commercial starter, grass silage, and hay. During the postweaning period (75 to $195 \mathrm{~d})$, the weaned calves had free access to grass silage and hay and were given $3 \mathrm{~kg} / \mathrm{d}$ (air-dry basis) of a commercial concentrate mixture. During the preweaning period, the water intake of the calves offered warm water was $47 \%$ higher than that of the calves offered cold water. Water intake in both treatments increased rapidly during weaning and for a few days following weaning. At 180 to $195 \mathrm{~d}$ of age, the calves consumed approximately 18 to $20 \mathrm{~L}$ of water daily. Calves offered warm water drank 7 and $8 \%$ more water during the postweaning period and overall during the experimental period, respectively, compared with those offered cold water. No treatment differences were observed in dry matter or energy intakes, body weight gains, or feed conversion rates. Furthermore, total serum IgG concentrations of the calves did not differ during the preweaning or postweaning periods. Dairy calves consumed more warm than cold water, but the increase in water intake did not influence feed intake, body weight gain, or health parameters.

Received August 14, 2010.

Accepted January 17, 2011.

${ }^{1}$ Corresponding author: Arto.Huuskonen@mtt.fi
Key words: dairy calf, water temperature, feed intake, growth

\section{INTRODUCTION}

Good health and growth performance of dairy calves are important aspects of dairy herd management. Before weaning, dairy calves are typically fed a restricted amount of milk or milk replacer, with the common daily recommendation being 8 to $10 \%$ of live weight at birth (Drackley, 2005). Kertz et al. (1984) reported that restrictively milk-fed calves that received water ad libitum ate more concentrates and gained more BW compared with calves that did not receive water. Hepola et al. (2008) concluded that the water source (open bucket or nipple) did not affect the total amount of water consumed, but the calves received water in smaller portions from water nipples than from open buckets.

In Finland, calves often receive cold water because drinking water is typically pumped from a well and served without heating. The effects of drinking water temperature on the performance and health of dairy calves have scarcely been studied. A few studies have examined the effect of offering heated (Andersson, 1985; Osborne et al., 2002) or chilled (Baker et al., 1988; Wilks et al., 1990) drinking water on the performance of dairy cows. In a hot environment, cooling of the water is of primary interest, whereas for high-yielding dairy cows in a cold environment it may be advantageous to warm the drinking water (Andersson, 1985). Andersson (1985) investigated the effect of 4 drinking water temperatures $\left(3,10,17\right.$, and $\left.24^{\circ} \mathrm{C}\right)$ on water intake, feed consumption, and milk yield of Swedish Red and White cows and reported that the coldest water $\left(3^{\circ} \mathrm{C}\right)$ caused a decrease in milk yield compared with all other treatments. On the other hand, Osborne et al. (2002) reported that cows drank more heated $\left(30\right.$ to $\left.33^{\circ} \mathrm{C}\right)$ water than water at ambient $\left(7\right.$ to $\left.15^{\circ} \mathrm{C}\right)$ temperature, but the increase in water intake did not influence milk yield. In cold environments, sheep (Shiga, 1986) and goats (Olsson and Hydbring, 1996) preferred the higher temperature of water when given a choice of ambient or heated 
drinking water. However, very limited information is available on the effects of drinking water temperature on dairy calves. Therefore, the present experiment was designed to study the effects on performance, health, and water consumption of offering either warm (16 to $\left.18^{\circ} \mathrm{C}\right)$ or cold $\left(6\right.$ to $\left.8^{\circ} \mathrm{C}\right)$ drinking water to dairy calves. It was hypothesized that the use of heated drinking water would increase the water intake of the calves and that the increased water intake might increase feed intake and improve gain.

\section{MATERIALS AND METHODS}

\section{Animals, Housing, and Experimental Design}

Treatment of the calves was approved by the Ethical Committee for Animal Experimentation (MTT AgriFood Research Finland, license number: PPO 3/04). The present experiment included 4 batches of 30 bull calves each. The first batch (comprising 21 Finnish Ayrshire and 9 Holstein-Friesian bull calves) started in August 2004, the second (20 Finnish Ayrshire and 10 HolsteinFriesian bull calves) in February 2005, the third (18 Finnish Ayrshire and 12 Holstein-Friesian bull calves) in September 2005, and the fourth (22 Finnish Ayrshire and 8 Holstein-Friesian bull calves) in May 2006, in the experimental barn of the North Ostrobothnia Research Station of MTT Agrifood Research Finland (Ruukki, $\left.64^{\circ} 44^{\prime} \mathrm{N}, 25^{\circ} 15^{\prime} \mathrm{E}\right)$.

All calves were purchased from local dairy farms. The calves were housed in an insulated barn in 6 pens $(3.0$ $\times 3.5 \mathrm{~m} ; 5$ calves in each), providing $2.1 \mathrm{~m}^{2} /$ calf. The floor of the pen was one-third metal slats and two-thirds rubber mats. Peat or straw was used as bedding during the preweaning period. The ambient temperature of the insulated barn varied between 11 and $20^{\circ} \mathrm{C}$ in winter (October-April) and between 15 and $23^{\circ} \mathrm{C}$ in summer (May-September). The calves were randomly (balanced for breed) allotted to pens ( 5 calves/pen), which were then randomly allotted to 2 experimental treatments: the calves were offered either warm $\left(\mathbf{W}, 16\right.$ to $\left.18^{\circ} \mathrm{C}\right)$ or cold $\left(\mathbf{C}, 6\right.$ to $\left.8^{\circ} \mathrm{C}\right)$ water during the experiment. Drinking water was stored in 2 water tanks in which water temperature was controlled automatically. A cold treatment of 6 to $8^{\circ} \mathrm{C}$ was chosen because it is the typical temperature in Finland when drinking water is pumped from a well and served without heating (Virta, 2003). A warm treatment of 16 to $18^{\circ} \mathrm{C}$ was chosen because it has been reported (Lofgreen et al., 1975) that cattle consume more feed, gain more weight, and improve energy utilization when given access to water at $18.3^{\circ} \mathrm{C}$ compared with warmer water at $32.2^{\circ} \mathrm{C}$.

Treatment W included 41 Ayrshire and 19 HolsteinFriesian bull calves and treatment C 40 Ayrshire and
20 Holstein-Friesian bull calves. At the beginning of the experiment, the average $\mathrm{BW}$ of the calves was 50.2 $\pm 3.0 \mathrm{~kg}$ (mean $\pm \mathrm{SD}$ ) and overall age was $20 \pm 2.5 \mathrm{~d}$. During the experimental period (20 to 195 d of age), the calves had free access to water from an open water bowl ( 1 bowl/pen). The bowls were $80 \mathrm{~mm}$ deep, 220 $\mathrm{mm}$ in diameter, and had a capacity of $2 \mathrm{~L}$. The water pipes were equipped with water meters that were read every day at $0700 \mathrm{~h}$.

\section{Feeding}

During the preweaning period (age 20 to $75 \mathrm{~d}$ ) the calves received a milk replacer (MR; at a dilution of $11.9 \%$ DM) supplied by Valio Ltd. (Valio, Finland). The MR included (\% of DM) skim milk powder (55.8), whey powder (24.5), lard (15.2), wheat starch (2.3), rapeseed oil (0.9), lecithin (0.4), $\mathrm{CaCl}_{2}(0.4), \mathrm{NaCl}(0.3)$, and vitamin-mineral premix (0.2). In both treatments, the MR was served by using a computer-controlled feeder (2 pens/feeder; Stand Alone 2 Plus, Förster, Engen, Germany; program: Kalbmanager 4.2). The feeding temperature of the MR was $37^{\circ} \mathrm{C}$. The calves were allocated to treatments at $20 \mathrm{~d}$ of age; from d 20 to 62 , the highest possible MR allowance of the calves was $7.5 \mathrm{~L}$. During the preweaning period, calves had free access to commercial pelleted calf starter, hay, and grass silage. The grass silages used in the experiment were harvested from first-year stands grown in Ruukki, Finland $\left(64^{\circ} 44^{\prime} \mathrm{N}, 25^{\circ} 15^{\prime} \mathrm{E}\right)$. The silages were prepared from primary growths of mixed Phleum pratense and Festuca pratensis stands and harvested at early stages of maturity. The silages were cut using a mower conditioner, wilted for $5 \mathrm{~h}$, and then harvested using a precision-chop forage harvester. The crops were ensiled using a formic-acid-based additive (AIV 2 Plus, Kemira GrowHow Ltd., Helsinki, Finland, containing, per kilogram of additive, $760 \mathrm{~g}$ of formic acid and $55 \mathrm{~g}$ of ammonium formate) applied at a rate of $6 \mathrm{~L} / \mathrm{t}$ of grass in bunker silos. The hay used in the experiment was not chopped and was prepared from mixed P. pratense and $F$. pratensis stands.

During the postweaning period (age 75 to $195 \mathrm{~d}$ ), the calves were fed grass silage and hay ad libitum, but the amount of concentrate was restricted to $3 \mathrm{~kg}$ (air dry)/calf daily. The commercial starter concentrate used during both the pre- and postweaning periods was supplied by Raisio Nutrition Ltd. (Raisio, Finland) and contained $20.5 \% \mathrm{CP}$ (\% of DM) and $12.3 \mathrm{MJ}$ of $\mathrm{ME} / \mathrm{kg}$ of DM. It comprised (\% of DM) barley (18.0), oats (13.0), wheat bran (11.0), rapeseed meal (9.5), rapeseed cake (8.0), molassed sugar-beet pulp (8.0), malted sprouted barley (5.5), wheat (5.0), wheat syrup (5.0), wheat feed meal (4.6), soybean meal (4.0), dis- 
tilled solubles (4.0), vegetable oil (0.2) and minerals and vitamins (4.2). The commercial starter concentrate was replaced by rolled barley and rapeseed meal when the calves were $135 \mathrm{~d}$ old; thereafter, the concentrate mixture contained $16.9 \% \mathrm{CP}$ and $13.2 \mathrm{MJ}$ of $\mathrm{ME} / \mathrm{kg}$ of DM. No medications were used in any of the feeds.

\section{Procedures, Calculations, and Sample Analyses}

Forage and concentrates were offered separately from a box feeder with proportional refusals at $5 \%$ in ad libitum feeding, and the calves were fed 3 times per day (at 0800, 1200, and $1800 \mathrm{~h}$ ). Refused feed was collected and measured daily at $0700 \mathrm{~h}$. Daily solid feed and water intake was weighed penwise (i.e., average for 5 calves). Feed samples for chemical analyses were taken twice a week and pooled over periods of 4 weeks. Samples were analyzed for DM, ash, CP, and NDF; silage was also analyzed for fermentation quality $[\mathrm{pH}$, water-soluble carbohydrates, lactic and formic acids, volatile fatty acids, soluble and ammonia- $\mathrm{N}$ content of $\mathrm{N}$ and digestible $\mathrm{OM}$ in DM (D value)]. Feed DM values were determined by oven drying. Silage DM was corrected for loss of volatiles (Huida et al., 1986). Ash was determined after ignition in a muffle furnace at $600^{\circ} \mathrm{C}$ for $18 \mathrm{~h}$. The CP content of feeds was determined using a Dumas-type N analyzer (Leco FP-428, Leco Corp., St Joseph, MI), and NDF was determined according to Van Soest et al. (1991). The silage was analyzed for fermentation quality by electrometric titration as described by Moisio and Heikonen (1989) and for D value by near-infrared spectroscopy as described by Nousiainen et al. (2004).

The ME values of silage and hay were calculated as $0.16 \times \mathrm{D}$ value $(\mathrm{MAFF}, 1975,1981)$. The ME values of concentrates and milk replacers were calculated as described by Schiemann et al. (1972) and MAFF (1975, 1984). The calves were weighed on 2 consecutive days at the beginning of the experiment and thereafter every $14 \mathrm{~d}$. Body weight gain (BWG) was calculated as the difference between the means of initial and final BW. Health parameters such as fecal consistency (normal or diarrhea), bloat, movements, cough, and inflammation (e.g., pneumonia, swollen joints, and hair loss) were monitored daily. Three calves from treatment $\mathrm{W}$ and 1 calf from treatment $\mathrm{C}$ were excluded from the study ( 2 due to pneumonia, 1 due to several occurrences of bloat, and 1 due to arthritis). It is unlikely that the treatments caused these problems.

At 20,60, 120, and $195 \mathrm{~d}$ of age, blood samples were collected from the calves. The immune status of the calves was estimated by determining serum total $\mathrm{IgG}$ concentration. In the morning before feeding, blood samples were collected into $9 \mathrm{~mL}$ tubes (Vacuette) by jugular venipuncture using 20-gauge needles. After centrifugation, $1 \mathrm{~mL}$ of serum was pipetted from each sample into 3 tubes, and stored first at $-12^{\circ} \mathrm{C}$ and then at $-70^{\circ} \mathrm{C}$ until assayed. The serum samples were assayed with an ELISA (Varley et al., 1985) modified for bovine IgG determination (Morrow-Tesch and Jones, 1997).

\section{Statistical Methods}

The present experiment included 4 batches of 30 bull calves each. The statistical analysis of BW and IgG was based on individual observations, the rest of the variables on pooled data. When batches were pooled, there were 12 pens $(60$ calves)/treatment. The pen (a group of 5 calves) was used as an experimental unit in all analyses, and animal was used as an observation unit when individual observations were used.

All variables were measured several times from the same animal or pen. Correlation of repeated measurements was taken into account. The following statistical model was used to analyze BW and $\operatorname{IgG}$ where individual observations were used:

$$
\begin{gathered}
y_{i j k l m}=\mu+\beta_{k}+\alpha_{j}+(\beta \times \alpha)_{j k}+e_{1}+e_{2}+\gamma_{l} \\
+(\beta \times \gamma)_{k l}+(\alpha \times \gamma)_{j l}+(\beta \times \alpha \times \gamma)_{j k l}+e_{3}+e_{4},
\end{gathered}
$$

where $y_{i j k l m}$ is the observation of the $i$ th animal ( $i=$ $1, \ldots, 120)$ placed into the $m$ th pen $(m=1, \ldots, 24), \mu$ is the intercept, $\beta_{k}$ is the effect of the $k$ th batch $(k=$ $1, \ldots, 4), \alpha_{j}$ is the effect of the $j$ th treatment $(j=1,2)$, $(\beta \times \alpha)_{j k}$ is the batch $\times$ treatment interaction effect, $e_{1}$ is the random effect associated with between-pen variation, and $e_{2}$ is the random effect associated with between-animal variation. The between-pen variation was used as an error term when differences between treatments were compared. The rest of the model includes the within-animal variation: $\gamma_{l}$ is the effect of the $l$ th time $(l=1, \ldots, 4),(\beta \times \gamma)_{k l}$ is the batch $\times$ time interaction effect, $(\alpha \times \gamma)_{j l}$ is the treatment $\times$ time interaction effect, $(\beta \times \alpha \times \gamma)_{j k l}$ is the batch $\times$ treatment $\times$ time interaction effect, $e_{3}$ is the random effect associated with pen-by-time interaction, and $e_{4}$ is the residual error. The pen-by-time interaction, $e_{3}$, was used as an error term in statistical comparisons related to the treatment $\times$ time interaction (e.g., differences in BWG).

Residuals of the same animal were correlated. Furthermore, the random variation increased when the animals' weight increased. Unstructured variance-covariance structure was chosen to model the correlation by Akaike's information criterion. A $\log _{\mathrm{e}}$-transformation was made for the IgG data before statistical analysis because of the skew distribution. All the estimates 
Table 1. Chemical composition and nutritional values of the feeds used in the experiment

\begin{tabular}{lcccccc}
\hline Item & $\begin{array}{c}\text { Milk } \\
\text { replacer }\end{array}$ & $\begin{array}{c}\text { Grass } \\
\text { silage }^{1}\end{array}$ & Hay & $\begin{array}{c}\text { Starter } \\
\text { concentrate }\end{array}$ & Barley & $\begin{array}{c}\text { Rapeseed } \\
\text { meal }\end{array}$ \\
\hline DM, \% & 96.5 & 25.9 & 83.0 & 87.5 & 89.0 & 88.1 \\
OM, \% of DM & 92.8 & 93.2 & 95.5 & 90.9 & 97.5 & 91.5 \\
CP, \% of DM & 21.0 & 16.6 & 5.5 & 20.5 & 12.7 & 35.2 \\
NDF, \% of DM & - & 53.1 & 68.2 & 24.9 & 18.6 & 26.1 \\
ME, MJ/kg of DM & 19.9 & 10.9 & 8.7 & 12.3 & 13.0 & 11.7 \\
\hline
\end{tabular}

${ }^{1}$ Fermentation quality of the grass silage: $\mathrm{pH} 4.1$; volatile fatty acids $1.6 \%$ of DM; lactic + formic acid $5.3 \%$ of DM; water-soluble carbohydrates $5.4 \%$ of DM; ammonia N $6.2 \%$ of total N; soluble $\mathrm{N} 50.1 \%$ of total N.

presented have been transformed back to the original scale, but the standard errors could not be transformed back.

The rest of the variables were measured at the pen level only. Accordingly, effects related to animals $\left(e_{2}\right.$ and $e_{4}$ ) were removed from the model. Residuals in the reduced model, $e_{3}$, from the same pen were correlated. Unstructured variance-covariance structure was selected to model the correlation by Akaike's information criterion. All statistical analyses were performed using the MIXED procedure in SAS (version 9.1, SAS Institute Inc., Cary, NC).

\section{RESULTS AND DISCUSSION}

The average chemical composition and calculated nutritional values of the feeds are presented in Table 1. The fermentation quality of silages was good, as indicated by low $\mathrm{pH}$ values and low contents of ammonia $\mathrm{N}$ and fatty acids. The silages used were restricted fermentation with high residual water-soluble carbohydrates concentration and low lactic acid concentration.
The calves in both treatments consumed less than 2 $\mathrm{L}$ of water daily between 20 and $62 \mathrm{~d}$ of age (Figure 1), which is similar to the amounts reported by Kertz et al. (1984) and Thomas et al. (2007). During the preweaning period, the water intake of the $\mathrm{W}$ calves was $47 \%$ higher $(P<0.001)$ compared with that of the $\mathrm{C}$ calves (Table 2). Water intake in both treatments increased rapidly during weaning and for a few days following weaning (Figure 1), which is in accordance with the results of Hepola et al. (2008). From 180 to 195 d of age the calves consumed approximately 18 to $20 \mathrm{~L}$ of water daily. Calves offered warm water drank 7 and $8 \%$ more water during the postweaning period $(P<0.10)$ and overall $(P<0.05)$, respectively, compared with those offered cold water. However, these differences were not significant. Also with dairy cows, Osborne et al. (2002) reported that cows consumed more of the heated (30 to $\left.33^{\circ} \mathrm{C}\right)$ drinking water than water at ambient $\left(7\right.$ to $\left.15^{\circ} \mathrm{C}\right)$ temperature.

During the preweaning and postweaning periods, the average DMI of the calves was 1.37 and $4.76 \mathrm{~kg}$ of $\mathrm{DM} / \mathrm{d}$, respectively, and the energy intake was 18.9 and

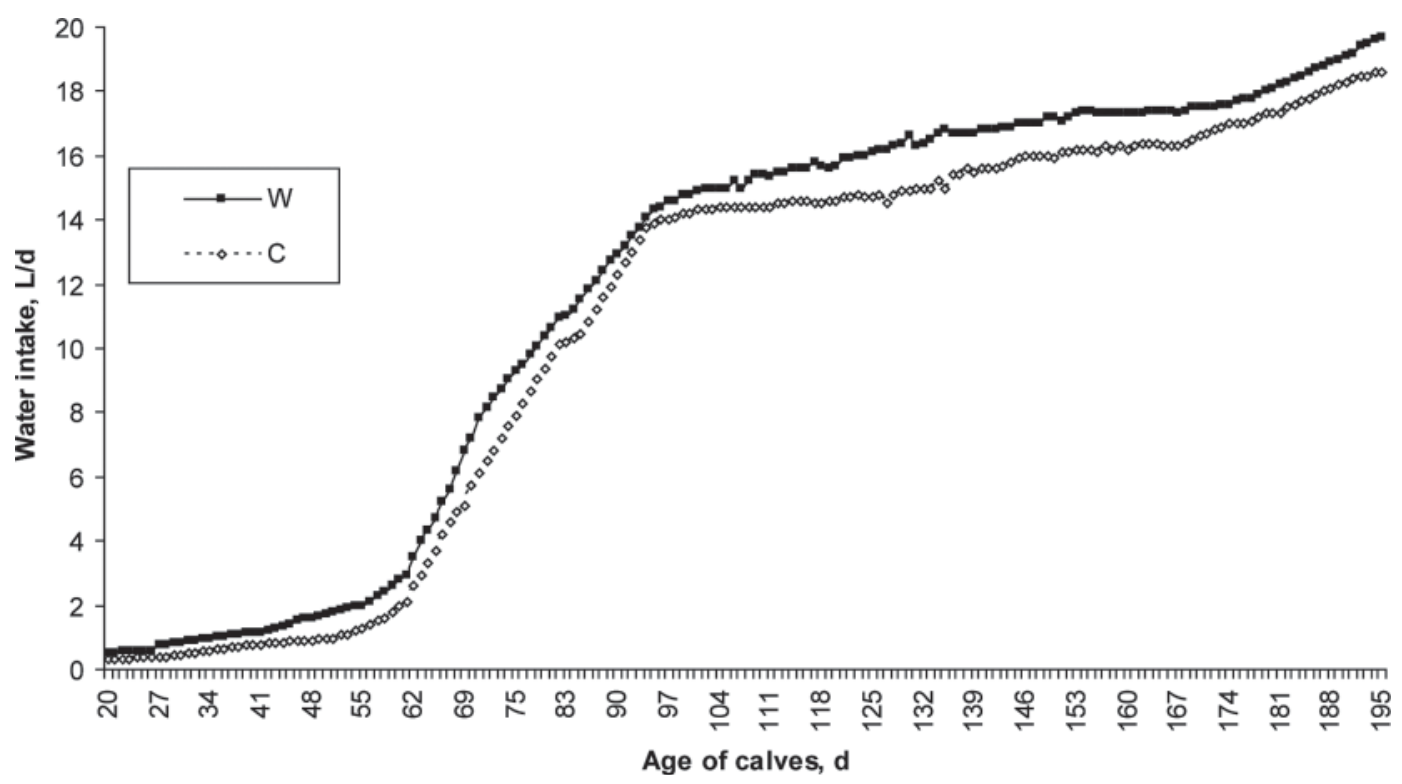

Figure 1. Daily water intake of dairy calves offered either warm (W, 16 to $\left.18^{\circ} \mathrm{C}\right)$ or cold $\left(\mathrm{C}, 6\right.$ to $\left.8^{\circ} \mathrm{C}\right)$ water. 
Table 2. Daily water and feed consumption, feed conversion ratio, BW gain (BWG), and total serum IgG concentration of dairy calves offered either warm $\left(16\right.$ to $\left.18^{\circ} \mathrm{C} ; \mathrm{n}=57\right)$ or cold $\left(6\right.$ to $\left.8^{\circ} \mathrm{C} ; \mathrm{n}=59\right)$ water

\begin{tabular}{|c|c|c|c|c|}
\hline Item & Warm & Cold & SEM & $P$-value \\
\hline \multicolumn{5}{|l|}{ Preweaning $^{1}$} \\
\hline Water intake, $\mathrm{L} / \mathrm{d}$ & 2.8 & 1.9 & 0.09 & $<0.0001$ \\
\hline Milk replacer, $\mathrm{kg}$ of $\mathrm{DM} / \mathrm{d}$ & 0.71 & 0.72 & 0.006 & 0.213 \\
\hline Concentrate, $\mathrm{kg}$ of $\mathrm{DM} / \mathrm{d}$ & 0.46 & 0.44 & 0.016 & 0.257 \\
\hline Roughage, ${ }^{2} \mathrm{~kg}$ of DM/d & 0.21 & 0.20 & 0.009 & 0.428 \\
\hline Total intake, $\mathrm{kg}$ of DM/d & 1.38 & 1.36 & 0.022 & 0.406 \\
\hline Energy intake, MJ of ME/d & 19.0 & 18.7 & 0.26 & 0.491 \\
\hline Feed conversion ratio, $\mathrm{MJ} / \mathrm{kg}$ of $\mathrm{BWG}$ & 28.4 & 27.2 & 0.64 & 0.202 \\
\hline \multicolumn{5}{|l|}{ Postweaning $^{3}$} \\
\hline Water intake, L/d & 16.3 & 15.3 & 0.36 & 0.080 \\
\hline Concentrate, $\mathrm{kg}$ of $\mathrm{DM} / \mathrm{d}$ & 2.59 & 2.59 & 0.004 & 0.291 \\
\hline Roughage, $\mathrm{kg}$ of DM/d & 2.20 & 2.14 & 0.048 & 0.370 \\
\hline Total intake, $\mathrm{kg}$ of DM/d & 4.79 & 4.73 & 0.050 & 0.347 \\
\hline Energy intake, MJ of ME/d & 56.5 & 55.7 & 0.55 & 0.326 \\
\hline Feed conversion ratio, $\mathrm{MJ} / \mathrm{kg}$ of $\mathrm{BWG}$ & 44.0 & 43.8 & 0.50 & 0.733 \\
\hline \multicolumn{5}{|l|}{ Average during the experiment } \\
\hline Water intake, L/d & 11.8 & 10.9 & 0.24 & 0.018 \\
\hline Milk replacer, $\mathrm{kg}$ of $\mathrm{DM} / \mathrm{d}$ & 0.24 & 0.24 & 0.002 & 0.213 \\
\hline Concentrate, $\mathrm{kg}$ of DM/d & 1.88 & 1.87 & 0.007 & 0.242 \\
\hline Roughage, $\mathrm{kg}$ of DM/d & 1.54 & 1.49 & 0.034 & 0.392 \\
\hline Total intake, $\mathrm{kg}$ of $\mathrm{DM} / \mathrm{d}$ & 3.66 & 3.60 & 0.039 & 0.339 \\
\hline Energy intake, MJ of ME/d & 44.0 & 43.4 & 0.43 & 0.332 \\
\hline Feed conversion ratio, $\mathrm{MJ} / \mathrm{kg}$ of $\mathrm{BWG}$ & 40.5 & 40.1 & 0.37 & 0.446 \\
\hline \multicolumn{5}{|l|}{$\mathrm{BW}, \mathrm{kg}$} \\
\hline Initial, at age of $20 \mathrm{~d}$ & 50.0 & 50.3 & 0.90 & 0.810 \\
\hline At the end of preweaning & 89.4 & 90.4 & 1.44 & 0.624 \\
\hline Final, at age of $195 \mathrm{~d}$ & 234.4 & 234.0 & 2.62 & 0.924 \\
\hline \multicolumn{5}{|l|}{ BWG, g/d } \\
\hline Preweaning & 702 & 715 & 19.6 & 0.661 \\
\hline Postweaning & 1,295 & 1,282 & 15.1 & 0.570 \\
\hline Average & 1,097 & 1,093 & 19.7 & 0.842 \\
\hline \multicolumn{5}{|l|}{$\mathrm{IgG}, \mathrm{mg} / \mathrm{mL}$} \\
\hline Initial, at age of $20 \mathrm{~d}$ & 2.0 & 2.2 & $\mathrm{NA}^{4}$ & 0.529 \\
\hline At the age of $60 \mathrm{~d}$ & 7.8 & 7.9 & NA & 0.967 \\
\hline At the age of $120 \mathrm{~d}$ & 9.8 & 10.4 & NA & 0.670 \\
\hline Final, at age of $195 \mathrm{~d}$ & 12.9 & 13.4 & NA & 0.768 \\
\hline
\end{tabular}

56.1 MJ of ME/d, respectively. Treatment did not affect DM or energy intake (Table 2). The average BWG of the calves during the preweaning and postweaning periods and during the entire experiment were 708 , 1,288 , and $1,094 \mathrm{~g} / \mathrm{d}$, respectively, which is in accordance with the results by Huuskonen et al. (2005) and Huuskonen and Khalili (2008), with dairy bull calves fed diets based on MR, grass silage, and grain in a similar housing environment. No differences in BWG, feed conversion rates, or BW were observed at the end of the weaning phase or at $195 \mathrm{~d}$ (Table 2). It can be concluded that the higher water intake of the $\mathrm{W}$ calves did not affect any measured intake or performance parameter compared with the $\mathrm{C}$ calves.

In total, $33 \%$ of the calves were treated at least once by a veterinarian (16 $\mathrm{C}$ calves and $23 \mathrm{~W}$ calves). The proportion is quite high but Roth et al. (2009), for example, reported an even higher proportion (49\%). According to Roth et al. (2009), the high proportion of treated calves underlines the high risk that is associated with regrouping of calves of young age originating from different farms. In total, respiratory diseases were treated 27 times (treatment C: 9 calves; treatment $\mathrm{W}: 18$ calves), omphalitis 6 times (C: 4 calves; W: 2 calves), dermatitis 6 times (C: 2 calves; W: 4 calves), and arthritis 3 times (C: 1 calf; W: 2 calves). Diarrhea was observed in $34 \%$ of the calves at least once (C: 21 calves; W: 20 calves) and bloating in $14 \%$ of the calves at least once (C: 9 calves; W: 8 calves).

Total serum IgG concentrations of the calves did not differ during the preweaning or postweaning periods (Table 2). The immune status of the calves was determined because it can be used as an index for long-term stress and disease susceptibility (Broom and Johnson, 
1993). The assumption that stress influences host immunity arises from observations of increased disease occurrence in animals exposed to extreme, stressful environments (Blecha, 2000). In the present experiment, no differences were observed between treatments in immune status or health of the calves; thus, no evidence existed that the intake of cold water $\left(6\right.$ to $\left.8^{\circ} \mathrm{C}\right)$ was a health risk for the calves.

\section{CONCLUSIONS}

The water consumption of calves was higher in calves offered warm water compared with those offered cold water during the preweaning period. However, the increased water intake of the calves offered warm water did not affect any measured intake or performance parameter compared with the calves offered cold water.

\section{ACKNOWLEDGMENTS}

The authors thank the Employment and Economic Development Centre for Northern Ostrobothnia (Oulu, Finland), MTT Agrifood Research Finland (Jokioinen, Finland), Savonia University of Applied Science (Iisalmi, Finland), and A-Farmers Ltd. (Atria, Finland) for financial support. The authors thank Lauri Jauhiainen for advice on statistical analysis. The authors also express their gratitude to Matti Huumonen and his staff at Animal Production Research in Ruukki for technical assistance and excellent care of the experimental animals. The personnel at Animal Production Research in Jokioinen are also thanked for the laboratory analyses.

\section{REFERENCES}

Andersson, M. 1985. Effects of drinking water temperatures on water intake and milk yield of tied-up dairy cows. Livest. Prod. Sci. 12:329-338.

Baker, C. C., C. E. Coppock, J. K. Lanham, D. H. Nave, J. M. Labore, C. F. Brasington, and R. A. Stermer. 1988. Chilled drinking water effects of lactating Holstein cows in summer. J. Dairy Sci. $71: 2699-2708$

Blecha, F. 2000. Immune system response to stress. Pages 111-122 in Biology of Animal Stress: Basic Principles and Implications for Animal Welfare. G. Moberg, ed. CABI Publishing, Wallingford, UK.

Broom, D. M., and K. G. Johnson. 1993. Stress and Animal Welfare. Chapman \& Hall, London, UK.

Drackley, J. K. 2005. Early growth effects on subsequent health and performance of dairy heifers. Pages 213-235 in Calf and Heifer Rearing. P.C. Garnsworthy, ed. Nottingham Univ. Press, Nottingham, UK.

Hepola, H. P., L. Hänninen, S. Raussi, P. Pursiainen, A.-M. Aarnikoivu, and H. Saloniemi. 2008. Effects of providing water from a bucket or a nipple on the performance and behavior of calves fed ad libitum volumes of acidified milk replacer. J. Dairy Sci. 91:1486-1496

Huida, L., H. Väätäinen, and M. Lampila. 1986. Comparison of dry matter contents in grass silages as determined by oven drying and gas chromatographic water analysis. Ann. Agric. Fenn. 25:215230.

Huuskonen, A., and H. Khalili. 2008. Computer-controlled milk replacer feeding strategies for group-reared dairy calves. Livest. Sci. 113:302-306.

Huuskonen, A., H. Khalili, J. Kiljala, E. Joki-Tokola, and J. Nousiainen. 2005. Effects of vegetable fats versus lard in milk replacers on feed intake, digestibility, and growth in Finnish Ayrshire bull calves. J. Dairy Sci. 88:3575-3581.

Kertz, A. F., L. F. Reutzel, and J. H. Mahoney. 1984. Ad libitum water intake by neonatal calves and its relationship to calf starter intake, weight gain, feces score, and season. J. Dairy Sci. 67:2964-2969.

Lofgreen, G. P., R. L. Givens, S. R. Morrison, and T. E. Bond. 1975 Effect of drinking water temperature on beef cattle performance. J. Anim. Sci. 40:223-229.

MAFF (Ministry of Agriculture, Fisheries and Food). 1975. Energy Allowances and Feeding Systems for Ruminants. Technical Bulletin 33. Her Majesty's Stationery Office, London, UK.

MAFF (Ministry of Agriculture, Fisheries and Food). 1981. Animal Science 1979. ADAS Agricultural Science Service, Research and Developments Reports. Reference Book 254. Her Majesty's Stationery Office, London, UK.

MAFF (Ministry of Agriculture, Fisheries and Food). 1984. Energy Allowances and Feeding Systems for Ruminants. Reference Book 433. Her Majesty's Stationery Office, London, UK.

Moisio, T., and M. Heikonen. 1989. A titration method for silage assessment. Anim. Feed Sci. Technol. 22:341-353.

Morrow-Tesch, J., and B. Jones. 1997. Behavioural and physiological responses of calves to castration when performed at weaning or 3 weeks prior to weaning. Pages 416-419 in Proc. 9th Int. Congr. Anim. Hygiene ISAH'97. H. Saloniemi ed. Int. Soc. Anim. Hygiene and Univ. Helsinki, Helsinki, Finland.

Nousiainen, J., S. Ahvenjärvi, M. Rinne, M. Hellämäki, and P. Huhtanen. 2004. Prediction of indigestible cell wall fraction of grass silage by near infrared reflectance spectroscopy. Anim. Feed Sci. Technol. 115:295-311.

Olsson, K., and E. Hydbring. 1996. The preference for warm drinking water induces hyperhydration in heat-stressed lactating goats. Acta Physiol. Scand. 157:109-114.

Osborne, V. R., R. R. Hacker, and B. W. McBride. 2002. Effects of heated drinking water on the production responses of lactating Holstein and Jersey cows. Can. J. Anim. Sci. 82:267-273.

Roth, B. A., N. M. Keil, L. Gygax, and E. Hillmann. 2009. Influence of weaning method on health status and rumen development in dairy calves. J. Dairy Sci. 92:645-656.

Schiemann, R., K. Nehring, L. Hoffmann, W. Jentsch, and A. Chudy. 1972. Energetische Futterbewertung und Energienormen. VEB Deutscher Landwirtschaftsverlag, Berlin, Germany.

Shiga, A. 1986. The effect of drinking water temperature in winter on water, magnesium and calcium metabolism in ewes. Jpn. J. Vet. Sci. $48: 893-899$.

Thomas, L. C., T. C. Wright, A. Formusiak, J. P. Cant, and V. R. Osborne. 2007. Use of flavored drinking water in calves and lactating dairy cattle. J. Dairy Sci. 90:3831-3837.

Van Soest, P. J., J. B. Robertson, and B. A. Lewis. 1991. Methods for dietary fiber, neutral detergent fibre and nonstarch polysaccharides in relation to animal nutrition. J. Dairy Sci. 74:3583-3597.

Varley, M. A., G. J. Rucklidge, R. J. Wilkinson, and A. Maitland 1985. Enzyme-linked immunosorbent assay for the measurement of immunoglobulin $\mathrm{G}$ concentrations in porcine plasma and colostrums. Res. Vet. Sci. 38:279-281.

Virta, P. 2003. Nautojen ja sikojen vedentarve ja juomalaitteistojen kunto. Thesis. Faculty of Veterinary Medicine, Department of Production Animal Medicine, University of Helsinki, Finland. (in Finnish).

Wilks, D. L., C. E. Coppock, J. K. Lanham, K. N. Brooks, C. C. Baker, W. L. Bryson, R. G. Elmore, and R. A. Stermer. 1990. Responses of lactating Holstein cows to chilled drinking water in high ambient temperatures. J. Dairy Sci. 73:1091-1099. 